preferably on a national basis, to assess the therapeutic value of hormones, alone or in combination with chemotherapy and irradiation.

We are indebted to Professor N. F. C. Gowing, who is a member of the British Testicular Panel, for reviewing the histological sections and for confirming the type of teratomas according to the panel's classification. Our gratitude is due to Dr. R. G. Jacomb, of Messrs. UpJohn Ltd., for generous supplies of medroxyprogesterone acetate.

\section{References}

Anderson, D. G. (1972). American fournal of Obstetrics and Gynecology, 113, 195.

Bloom, H. J. G. (1964). In Tumours of the Kidney and Ureter, ed. E. W. Riches, p. 311 . London, Livingstone.

Bloom, H. J. G. (1971). British fournal of Cancer, 25, 250.

Bloom, H. J. G. (1972). In Endocrine Therapy in Malignant Disease, ed. B. Stoll, p. 339. London, Saunders.

Bloom, H. J. G. (1973). Cancer (Philadelphia). In press.

Briggs, M. H., Caldwell, A. D. S., and Pitchford, A. G. (1967). Hospital Medicine, 2, 63.

Coutts, W. E., and Vargas-Zalazar, R. (1945). Revista Chilena de Higiene $y$ Medicina Preventiva, 7, 57.
Cox, J. D., Gingerelli, F., Ream, N. W., and Maier, J. G. (1972). Radiology,

Daly, D. W., Dossett, J. A., and Jull, J. W. (1963). British fournal of Surgery,

50, 816.
Davis, P. L., and Shumway, M. H. (1958). Fournal of Urology, 80, 62.

Duari, M. (1967). British Fournal of Clinical Practice, 21, 195.

Ericsson, R. J., and Dutt, R. H. (1965). Endocrinology, 77, 203.

Everson, T. C., and Cole, W. H. (1966). Spontaneous Regression of Cancer. Philadelphia, Saunders.

Fedon, M. (1960). Chirurgia Italiana, 12, 458.

Foley, J. F., Lemon, H. M., Miller, D. M., and Kessinger, A. (1972). Fournal of Urology, 108, 439.

Friedman, N. B. (1951). Cancer (Philadelphia), 4, 265.

Hill, G. J., et al. (1972). Cancer (Philadelphia), 30, 900

Källén, B., and Röhl, L. (1962). Fournal of Urology, 87, 906.

Kennedy, B. J. (1970). Cancer (Philadelphia), 26, 735.

McClelland, J. C., and Richards, G. E. (1945). Transactions of the American Association of Genitourinary Surgeons, 35, 113.

Mackenzie, A. R. (1966). Cancer (Philadelphia), 19, 1369.

Mackenzie, A. R. (1966). Cancer (Philadelphia), 19, 1369.
Myers, L. M. (1959). Fournal of Pathology and Bacteriology, 78, 43. Clinical Endocrinology and Metabolism, 28, 679.

Ronzoni, G., Milano, S., Marin, A. W., and Pagliari, G. (1969). Chirugia e Patologia Sperimentale, 17, 101.

Samuels, M. L., Sullivan, P., and Howe, C. D. (1968). Cancer (Philadelphia), 22, 525.

Shivers, C. H. de T., and Axilrod, H. D. (1952). Fournal of Urology, 67, 537.

Smithers, D. W. (1972). British fournal of Urology, 44, 217.

Twombly, G. H. (1944). Surgery, 16, 181

Werf-Messing, B. Van der. (1973). Clinical Radiology, 24, 121.

\title{
Treatment of Acute Myeloid Leukaemia according to the Hammersmith Protocol: Preliminary Report
}

\author{
W. PAOLINO, L. RESEGOTTI, M. ROSSI, V. INFELISE
}

British Medical fournal, 1973, 3, 567-568

\section{Summary}

A preliminary report is given of a trial of the T.R.A.P. regimen (thioguanine, rubidomycin, cytosine arabinoside, and prednisolone) for the treatment of acute myeloid leukaemia. Out of 27 patients treated $13(48.1 \%)$ obtained complete remission. The treatment was well tolerated and produced especially good results in elderly patients.

\section{Introduction}

Modern therapeutic regimens produce complete remission in most cases of lymphoblastic leukaemia. In contrast the results so far obtained in acute myeloid leukaemia (A.M.L.) are more disappointing, and thus intensive research is needed in this field. We report here the results of a one-year trial of the Hammersmith Hospital protocol as reported by Spiers (1972) for the treatment of patients with A.M.L.

\section{Material and Methods}

Twenty-seven patients were admitted to the trial; 18 were new cases and 9 were already under treatment when the protocol was

\footnotetext{
Departments of Medicine and Haematology, St. John the Baptist Regional Hospital of Turin, Italy

W. PAOLINO, M.D., Consultant Physician and Head of Department

M. ROSSI, M.D., Assistant Physician

V. INFELISE, M.D., Assistant Physician

University of Turin, Italy

L. RESEGOTTI, M.D., Lecturer in Haematology
}

adopted. The latter patients were included either because they had relapsed after a first remission or because a remission could not be obtained with their previous therapy. We have not, however, adopted this protocol for maintenance treatment of patients already in remission induced by other drug combinations. Of the patients studied 16 were women and 11 men. Their distribution according to age is shown in table I.

Treatment was carried out with a modified version of the regimen designated T.R.A.P. by Spiers (1972)-namely, thioguanine $120 \mathrm{mg}$ daily by mouth for five days, rubidomycin (daunorubicin) $40 \mathrm{mg}$ intravenously on day 1 , cytarabine 150 $\mathrm{mg}$ daily intravenously for five days, and prednisolone $50 \mathrm{mg}$ daily by mouth for five days. Each course lasted five days and was administered six times with intervening rest periods of nine days. In two patients with major abnormalities in the E.C.G. at the time of diagnosis we began treatment with C.O.A.P. (Cytoxan (cyclophosphamide), Oncovin (vincristine) A.R.A.C. (cytarabine), and prednisone; Whitecar et al., 1970) and then changed to T.R.A.P. when the E.C.G. showed reversion to normal. After the first six courses (which we regarded as the period of remission induction, even if remission was obtained after three or four courses) treatment was changed to two courses of T.R.A.P. alternating with two courses of C.O.A.P. Supportive measures included blood and platelet transfusions and administration of antibiotics. The treatment was started in hospital and continued in the outpatient department after remission had been achieved.

Remission was regarded as complete when the patient became clinically free of disease and had a normal bone marrow, no anaemia, leucocytes above $2,000 / \mathrm{mm}^{3}$, with more than 1,000 neutrophils, and platelets above $100,000 / \mathrm{mm}^{3}$; and as incomplete when the clinical picture became normal but there were occasional blast cells in the blood or severe neutropenia or thrombocytopenia was present. Failure was inferred when there was no substantial haematological improvement. 


\section{Results}

The results are summarized in tables I and II. Complete remissions were obtained in $13(48.1 \%)$ patients and incomplete remissions in $5(18.5 \%)$.

TABLE I-Frequency of Remission in 27 Patients with A.M.L.

\begin{tabular}{|c|c|c|c|c|}
\hline Haematological Type & $\begin{array}{l}\text { No. of } \\
\text { Cases }\end{array}$ & $\begin{array}{l}\text { Complete } \\
\text { Remission }\end{array}$ & $\begin{array}{l}\text { Incomplete } \\
\text { Remission }\end{array}$ & Failure \\
\hline $\begin{array}{l}\text { Stem-cell leukaemia } \\
\text { Myeloblastic leukaemia } \\
\text { Myelomonocytic leukaemia } \\
\text { Promyelocytic leukaemia } \\
\text { Erythroleukaemia .. }\end{array}$ & $\begin{array}{r}7 \\
10 \\
7 \\
2 \\
1\end{array}$ & $\begin{array}{l}1 \\
7 \\
5 \\
0 \\
0\end{array}$ & $\begin{array}{l}1 \\
2 \\
2 \\
0 \\
0\end{array}$ & $\begin{array}{l}5 \\
1 \\
0 \\
2 \\
1\end{array}$ \\
\hline Total & 27 & $13(48 \cdot 1 \%)$ & $5(18.5 \%)$ & $9(33.3 \%$ \\
\hline
\end{tabular}

TABLE II-Relation between Age and Incidence of Remission

\begin{tabular}{|c|c|c|c|c|c|c|c|c|}
\hline Age in years: & & $10-20$ & -30 & -40 & -50 & -60 & -70 & -80 \\
\hline $\begin{array}{l}\text { No. with complete } \\
\text { remission } \\
\begin{array}{ll}\text { No. with incomplete } \\
\text { remission } & . \\
\text { No. of failures } & \ldots\end{array}\end{array}$ & $\begin{array}{l}\cdots \\
\cdots \\
\cdots\end{array}$ & $\begin{array}{l}2 \\
1 \\
1\end{array}$ & $\frac{1}{3}$ & 1 & 3 & $\begin{array}{l}5 \\
1 \\
1\end{array}$ & $\begin{array}{l}3 \\
1\end{array}$ & $\begin{array}{l}2 \\
1 \\
1\end{array}$ \\
\hline
\end{tabular}

At the time of writing we were unable to evaluate survival in these patients as 10 were still alive. Among the 17 dead the mean survival was 5.2 months; in those still alive, however, this would be appreciably longer, as nine of them were still in complete remission.

\section{SIDE EFFECTS}

Treatment was tolerated fairly well by most patients. The most common side effects were nausea and vomiting, leucopenia, alopecia, and facial rashes.

Nausea and vomiting occurred in all patients, at least on the first day of each course of treatment, but could be controlled easily by the administration of metoclopramide. Leucopenia was a major problem, as most of our patients were already leucopenic before the beginning of treatment, and in eight cases the neutrophil count was zero. We therefore decided to treat all patients with hypercellular blastic marrow with six courses of T.R.A.P. irrespective of the leucocyte count. The W.B.C. dropped below $1,000 / \mathrm{mm}^{3}$ in two cases and below $2,000 / \mathrm{mm}^{3}$ in 10; however, only one of these patients died before the end of the induction period, while six patients who were not so severely leucopenic died within the first month of treatment.

When remission was obtained the leucocyte count ranged between 2,000 and $8,000 / \mathrm{mm}^{3}$ in all patients; in four instances he interval between the maintenance courses had to be in- creased to 16 days because the W.B.C. had dropped below $2,000 / \mathrm{mm}^{3}$

Alopecia occurred in two cases and a facial rash in one. In no case was cardiotoxicity noticed. However, we administered $0.4 \mathrm{mg}$ deslanoside (Cedilanid) intravenously 30 minutes before the injection of daunorubicin. Deslanoside competes with daunorubicin for the same cardiac receptors, thus decreasing the toxicity of daunorubicin.

\section{Discussion}

The short period of observation and the small numbers of treated patients do not permit direct comparison of our results with those previously reported by other workers. The proportion of remissions obtained by us, however, does not differ greatly from those reported by Crowther et al. (1973) with daunorubicin (in double the doses used by us) and cytarabine, by Whitecar et al. (1972) with C.O.A.P., and by Gee et al. (1969) with thioguanine and cytarabine.

It is notable that in our study the incidence of remission in the older patients has been high compared with results from other centres (Crowther et al., 1973). This difference could be explained by our use of relatively small doses of the more toxic drugs. It is possible that this results in treatment that is better tolerated and more effective in the elderly while at the same time being insufficient for the treatment of some young patients.

One aspect of the results worth noting was the less favourable responses of patients with stem-cell, promyelocytic, and erythroleukaemic types of leukaemia when compared with those with myeloblastic and myelomonocytic disease. Of the 10 patients with the former types of A.M.L. eight were less than 50 years old, so the poorer results in our young patients could be associated with the unequal distribution of the different types of leukaemia with respect to age.

The inclusion of more patients in the trial will allow us to elucidate this point. At present our observations suggest that the dose of daunorubicin should be increased in the younger patients, or at least in those with stem-cell leukaemia.

Our experience suggests that the Hammersmith protocol is especially suitable for the treatment of A.M.L. because it produces a good proportion of remissions with only moderate toxicity to the patient and with only short periods of stay in hospital.

We express our gratitude to Dr. J. M. Goldman, M.R.C. Leukaemia Unit, Hammersınith Hospital, London, for his valuable help.

\section{References}

Crowther, D., et al. (1973). British Medical fournal, 1, 131. Gee, T. S., Yu, K. P., and Clarkson, B. C. (1969). Cancer (Philadelphia), 23,

Spiers, A. S. D. (1972). Clinics in Haematology, 1, 127.

Whitecar, J. P., Bodey, G. P., and Freireich, E. J. (1970). Proceedings of the American Association for Cancer Research, 11, 83, abstract No. 329.

Whitecar, J. P., Bodey, G. P., Freireich, E. J., McCredie, K. B., and Hart, J. S. (1972). Cancer Chemotherapy Reports, 56, 543. 